\title{
In the News
}

How well libraries and librarians satisfy the information needs of users is one of the primary means of measuring the library's success. Many factors affect the outcome of each information transaction and one important factor is the quality of the staff. Equally important are hiring competent staff, training them, and continuing to provicle them with professional development opportunities. An approach of continual learning helps individuals achieve their potential to do their best for the organization.

ACRL expressed its commitment to the importance of professional development when it adopted as the first goal of its strategic plan, "to provide development opportunities for academic librarians and other library personnel that enhance their ability to deliver superior services and resources." ACRL offers through its publications, workshops, and conferences many ways for librarians to update their skills.

In this issue, ACRL announces nine practical, skill-building workshops offered as preconferences to the ACRL National Conference in Nashville, April 11-14, 1997. Topics cover a wide spectrum of interests including fundraising, new learning communities, digital information, digitizing collections, preferred futures, buildings, the learning organization, technical services workstations, and user needs (page 667).

Two articles in this issue address the advantages of staff development. Peggy Johnson descrilbes a cross-training program planned and implemented at the University of Minnesota (page 644). And Anita Lowry, Paul Soderdahl, and Barbara Dewey clescribe how the University of Iowa developed a flexible team structure to manage its Web-based information system (page 640). Giving staff the opportunity to learn new skills and to participate in librarywide projects benefits both individuals and organizations.

- Mary Ellen K. Davis Editor E Publisher medavis@ala.org

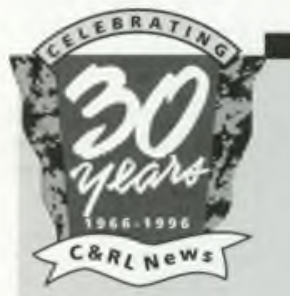

\section{C\&RL News 30th anniversary quiz}

What do you recall reading in CERL News the past 30 years? To celebrate the News' 30th anniversary, the Editorial Board and editors of CGRL Neus have written questions based on news and articles published since the Neus' inception in 1966. Five questions (and answers) will be published each month to help you wend your way through the past 30 years of academic librarianship as reported by CERL Neus. We hope you have as much fun answering these cuestions as we did writing them. If you have a question you'd like considered for the quiz please send it to Mary Ellen Davis at meclavis@ala.org.
1. The American Antiquarian Society acquired the only known copy of the first novel published in America. Give the author, title, publishing information of this early work, and when the Society acquired it.

2. Who was the first woman to hold the position of executive secretary of ACRL and when was she appointed?

3. When was the federal wiretap law first updated to "protect against unauthorized interception of electronic communications?"

4. What state chapter held its first annual meeting in 1980 ?

5. Which university dedicated a "solar" library in 1982 ?

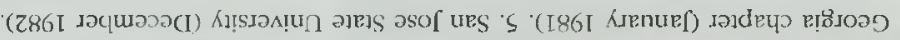

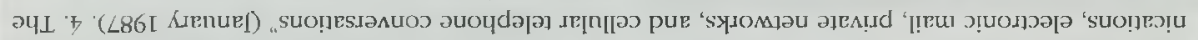

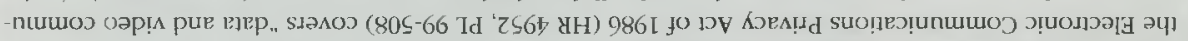

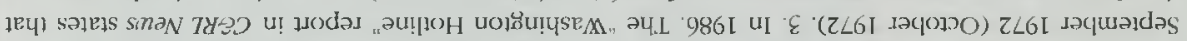

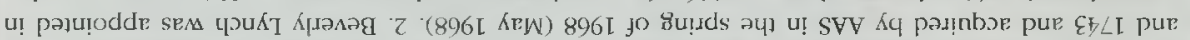

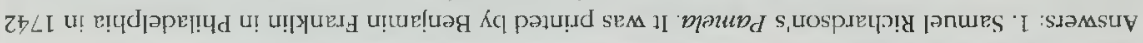

